\title{
KARAKTERISTIK KARKAS SAPI PERANAKAN SIMMENTAL JANTAN \\ DI RUMAH POTONG HEWAN KOTA SEMARANG \\ Carcass Characteristics of Simmental Crossbreed Cattle Slaughtered at Semarang City \\ Slaughterhouse
}

\author{
M.H. Ridwan, M. Arifin dan E. Purbowati \\ Fakultas Peternakan dan Pertanian, Universitas Diponegoro \\ Jalan Prof. H Soedarto, SH, Tembalang 50275, Semarang \\ e-mail : muhammadhildaridwan@gmail.com
}

\begin{abstract}
This study aims to assess and characterize the products of slaughter (carcass) Simmental bull crossbreed cattle slaughtered in the Slaughter House Semarang in March to April 2016. The material is used as the object is 60 Simmental bull crossbreed catlle were slaughtered in RPH Semarang, the catlles are selected by looking at the characteristics Simmental bull crossbreed cattle is white on the forehead, with a horn in black and yellow, have nail color and tail hair of black, yellow, and white, and has a body color of brown and red brick. The variables were observed in this study were age, slaughter weight, carcass weight, carcass percentage, as well as the quality grade. The results showed that the average Simmental bull crossbreed catlle were slaughtered in slaughterhouses Semarang own age $3 \pm 0.60$ years, slaughter weight $572 \pm 130.85 \mathrm{~kg}$, carcass weight $312 \pm 66.00 \mathrm{~kg}$, carcass percentage $51.5 \pm 1.25 \%$, and quality grade choice. Conclusion the results of the study are cattle crossbreed Simmental were slaughtered in slaughterhouses Penggaron Semarang still less optimum (age 3 years, slaughter weight $572 \mathrm{~kg}$, carcass weight $312 \mathrm{~kg}$, carcass percentage $51.5 \%$, and quality grade choice) and still has the potential for improved productivity in terms of both quantity and quality, and thus the expected productivity of cattle crossbreed Simmental in Indonesia can be increased so as to support efforts to increase the productivity of national beef catlle.
\end{abstract}

Keywords: Simmental crossbreed cattle, carcass, quality grade.

\begin{abstract}
ABSTRAK
Penelitian ini bertujuan untuk menilai serta melakukan karakterisasi produk hasil pemotongan (karkas) sapi peranakan Simmental jantan yang dipotong di Rumah Potong Hewan Kota Semarang pada bulan Maret sampai dengan bulan April 2016. Materi yang digunakan sebagai obyek penelitian adalah 60 ekor sapi peranakan Simmental jantan yang dipotong di RPH Kota Semarang, sapi-sapi tersebut dipilih dengan cara melihat karakteristik sapi Peranakan Simmental yaitu warna putih pada kening, memiliki tanduk dengan warna hitam maupun kuning, memiliki warna kuku dan bulu ekor hitam, kuning, dan putih, serta memiliki warna badan coklat dan merah bata. Variabel yang diamati dalam penelitian ini adalah umur, bobot potong, bobot karkas, persentase karkas, serta quality grade. Hasil penelitian menunjukkan bahwa rata-rata sapi peranakan Simmental yang dipotong di RPH Kota Semarang memiliki umur $3 \pm 0,60$ tahun, bobot potong $572 \pm 130,85$ $\mathrm{kg}$, bobot karkas $312 \pm 66,00 \mathrm{~kg}$, persentase karkas $51,5 \pm 1,25 \%$, dan quality grade choice. Simpulan hasil penelitian yaitu sapi peranakan Simmental yang dipotong di RPH Penggaron Kota Semarang masih kurang optimum (umur 3 tahun, bobot potong $572 \mathrm{~kg}$,
\end{abstract}


bobot karkas $312 \mathrm{~kg}$, persentase karkas 51,5\%, dan quality grade choice) dan masih memiliki potensi untuk ditingkatkan produktivitasnya baik dari segi kuantitas maupun kualitas, sehingga dengan demikian diharapkan produktivitas sapi peranakan Simmental di Indonesia dapat meningkat sehingga dapat menunjang upaya peningkatan produktivitas sapi nasional.

Kata kunci : sapi peranakan Simmental, karkas, quality grade.

\section{PENDAHULUAN}

Daging sapi merupakan komoditas penting bagi masyarakat Indonesia. Daging sapi merupakan bahan pangan sumber protein hewani yang sangat penting guna mencukupi kebutuhan gizi masyarakat, komoditas ini juga memiliki sumbangan penting dalam bidang ekonomi, karena diproduksi oleh sistem yang memiliki sejumlah besar masyarakat dari skala kecil sampai besar. Namun demikian upaya untuk memenuhi kebutuhan daging secara nasional tidak pernah berhasil atau menunjukkan hasil yang memuaskan. Data statistik konsumsi daging sapi secara nasional menunjukkan penurunan dari tahun 2012 yaitu sebesar 365 gram/kapita/tahun, tahun 2013 dan 2014 masing-masing sebesar 261 gram/kapita/ tahun ; sedangkan jumlah impor sapi mengalami kenaikan pada tahun 2013 yaitu sebesar 1.293.340 ekor dan tahun 2014 sebesar 1.435.706 ekor (Direktorat Jenderal Peternakan dan Kesehatan Hewan, 2015). Dari ilustrasi di atas maka dapat disimpulkan bahwa produksi daging yang belum mencukupi kebutuhan konsumsi masyarakat menuntut upaya dalam peningkatkan produktivitas daging sapi yang dibudidayakan oleh peternak.

Salah satu upaya yang dapat dilakukan dalam peningkatan produktivitas daging sapi lokal yaitu dengan melakukan standarisasi produksi daging sapi yang selenggarakan oleh peternak. Standar produksi tersebut sangat penting bagi pelaku usaha dibidang penggemukan sapi, karena dapat digunakan sebagai acuan tujuan penggemukan yang optimum, disamping itu juga dapat digunakan sebagai acuan bagi para jagal (butcher) dalam memilih sapi potong supaya dapat menghasilkan karkas yang maksimal. Menurut USDA (1996) standar produksi pemotongan sapi meliputi yield grade yang menggambarkan jumlah daging layak konsumsi yang akan dihasilkan, dan quality grade yang menggambarkan tingkat preferensi konsumen terhadap daging yang disahilkan.

Penelitian ini bertujuan untuk mengukur karakteristik produk pemotongan sapi peranakan Simmental Jantan di RPH Kota Semarang yang hasilnya diharapkan dapat dimanfaatkan baik oleh pelaku bisnis penggemukan, jagal (butcher), maupun pemerintah untuk memprebaiki upaya peningkatan produksi daging.

\section{MATERI DAN METODE}

Penelitian karakteristik karkas sapi peranakan Simmental jantan di rumah potong hewan Kota Semarang telah dilaksanakan dengan metode studi kasus pada bulan Maret 2016 - April 2016.

Materi yang digunakan sebagai obyek penelitian adalah 60 ekor sapi peranakan Simmental jantan yang dipotong di RPH Kota Semarang dengan karakteristik yaitu warna putih pada kening, memiliki tanduk dengan warna hitam maupun kuning, memiliki warna kuku dan bulu ekor hitam, kuning, dan putih, serta memiliki warna badan coklat dan merah bata (Syafrizal, 2011). 
Variabel yang diamati dalam (Murtidjo, 1992). Bobot potong diukur penelitian ini adalah umur, bobot potong, menggunakan timbangan bobot badan sapi bobot karkas, persentase karkas, serta pada beberapa jam sebelum sapi dipotong. quality grade.

Umur sapi dilihat melalui pergantian gigi seri susu menjadi gigi seri tetap ( $p o e l$ ), poel 1 menunjukkan sapi berumur 1-2 tahun, poel 2 sapi berumur 2-3 tahun, poel 3 sapi berumur 3-4 tahun dan poel 4 menunjukkan sapi berumur 4-5 tahun Ilustrasi 1)

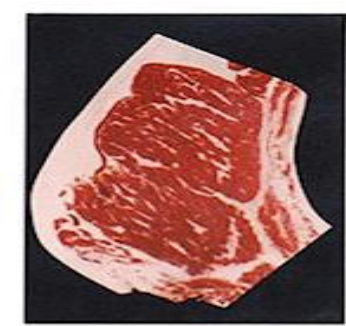

Moderately Abundant

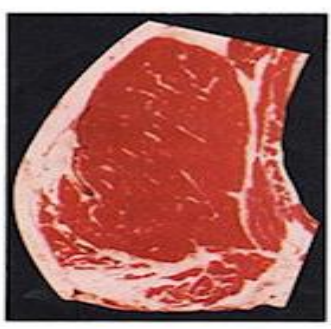

Modest

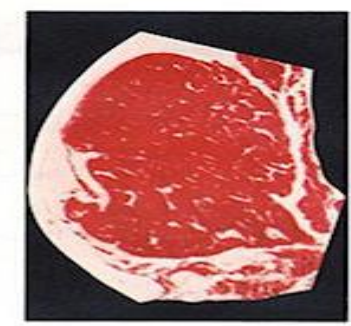

Slightly Abundant

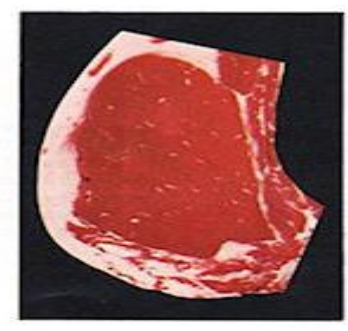

Small

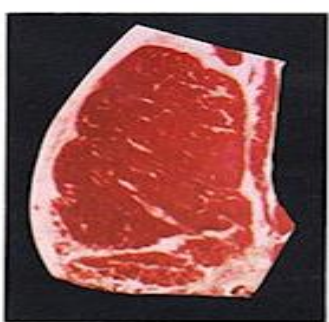

Moderate

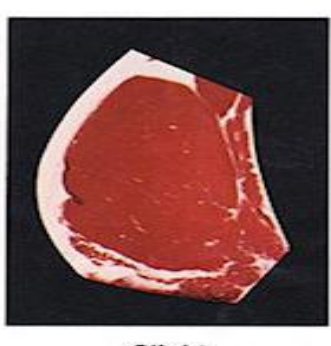

Slight

Ilustrasi 1. Marbling pada Bagian Rib Eye Muscle Area (USDA, 1996)

Quality grade dinilai dengan metode USDA (1996), yaitu melalui pengamatan pada kategori umur ternak (Lihat Tabel 1) dan marbling (tingkat perlemakan intramuscular yang tersebar pada rib eye muscle area pada potongan rusuk ke-12/13 (Lihat Ilustrasi 1), kemudian membandingkan hubungan keduanya dan membandingkan hasilnya dengan USDA quality grades for beef (Lihat Ilustrasi 2). Penilaian USDA quality grade meliputi 8 kategori yaitu USDA Prime, Choice, Select, Standard, Commercial, Utility, Cutter, dan Canner. Data penelitian ini kemudian dianalisis dan dibahas secara deskriptif.

Tabel 1. Kategori Umur Ternak

\begin{tabular}{cc}
\hline \hline Kategori & Umur \\
\hline A & $9-30$ bulan \\
B & $30-42$ bulan \\
C & $42-72$ bulan \\
D & $72-96$ bulan \\
E & Lebih dari 96 bulan \\
\hline
\end{tabular}

Sumber : USDA (1996)

$+$

Pengaruh Penggunaan Tepung Daun Mengkudu (Morinda cirifolia) dalam Pakan Terhadap Kualitas 
Ilustrasi 2. Hubungan antara Marbling, Umur dan Quality Grade

\begin{tabular}{|c|c|c|c|c|c|}
\hline \multirow{2}{*}{$\begin{array}{l}\text { Degrees of } \\
\text { Marbling }\end{array}$} & \multicolumn{5}{|c|}{ Maturity $^{2}$} \\
\hline & $A^{3}$ & B & C & D & $\mathrm{E}$ \\
\hline $\begin{array}{l}\text { Slightly } \\
\text { Abundant }\end{array}$ & PRIME & & & & \\
\hline Moderate & & & COMMERCIAL & COMMERCIAL & \\
\hline Modest & CHOICE & & & & \\
\hline Small & & & & & \\
\hline Slight & SELECT & & UTILITY & UTILITY & \\
\hline Traces & & & & & \\
\hline $\begin{array}{l}\text { Practically } \\
\text { Devoid }\end{array}$ & STANDARD & & & CUTTER & \\
\hline
\end{tabular}

Karkas Sapi Peranakan Simmetal Jantan (USDA, 1996)

\section{HASIL DAN PEMBAHASAN}

Hasil penelitian ini menunjukkan bahwa rata-rata sapi peranakan Simmental di RPH kota Semarang dipotong pada umur 3 tahun dengan bobot potong $572 \mathrm{~kg}$. Ratarata bobot maupun persentase karkas sapi peranakan Simmental yang dipotong di RPH kota Semarang terlalu rendah (Tabel 2) jika dibandingkan dengan Fiems et al. (2003) dan Waritthitham et al. (2010). Demikian pula jika dilihat dari sisi kualitas karkas yang dihasilkan kurang maksimal yakni rata-rata quality grade pada kisaran choice dan tingkat marbling pada modest. Nilai marbling maupun quality grade yang belum maksimal disebabkan oleh faktor perlemakan dalam tubuh serta nilai BCS sapi sebelum dipotong. Rossi dan Wilson (2006) menyebutkan bahwa sapi dengan nilai BCS 6 memiliki persentase lemak tubuh sebesar 22,61\% dengan kondisi tubuh bagian ribs tidak terlihat kasat mata, perototan yang penuh pada bagian hindquarters dan perlemakan terlihat pada tail head dan menutupi bagian ribs depan. Menurut USDA (1996), kondisi marbling pada bagian rib eye muscle area (RMA) dengan kategori small, modest dan moderate akan menghasilkan quality grade choice. Badriyah (2014) menjelaskan bahwa bobot badan bisa digunakan peternak sapi potong sebagai indikator keberhasilan pemeliharaan dan pertumbuhan sapi yang telah dipelihara apakah sesuai dengan harapan atau tidak.

Kualitas karkas yang dihasilkan dari pemotongan sapi peranakan Simmental di RPH Kota Semarang masih belum maksimal (belum mencapai prime), walaupun demikian nilai rata-rata karkas yang dihasilkan sudah relatif bagus, yaitu choice. Jika dilihat dari nilai marbling, karkas yang dihasilkan dari pemotongan sapi peranakan Simmental di RPH Penggaron Kota Semarang masih belum maksimal yaitu masih pada tingkat modest. Holland dan Loveday (2013) menjelaskan bahwa karkas dengan quality grade prime 
memiliki marbling paling bagus yaitu slightly abundant, choice memiliki nilai marbling small hingga moderate, select memiliki tingkat marbling slight dan quality grade standard memiliki kondisi marbling trace dan practically devoid. Tatum (1997) menjelaskan bahwa sesuai dengan pedoman USDA (1996) yang umum digunakan, karkas dengan kualitas prime, choice, select dan standard akan diperoleh dari sapi dengan kisaran umur $1-3,5$ tahun, sedangkan karkas dengan kualitas comercial, utility, cutter dan canner akan dihasilkan dari sapi dengan kisaran umur lebih dari 3,5 tahun. Berdasarkan fakta di atas dapat disimpulkan bahwa kualitas daging sapi yang dipotong di RPH Kota Semarang masih dapat ditingkatkan di atas choice melalui peningkatan body condition score di atas 6 dengan pembatasan umur potong 1 - 3,5 tahun.

Tabel 2. Nilai Rata-Rata Hasil Pengukuran Parameter Karkas Sapi Peranakan Simmental di RPH Kota Semarang

\begin{tabular}{|c|c|c|c|c|}
\hline \multirow[b]{2}{*}{ Parameter } & \multirow[b]{2}{*}{ Kisaran } & \multirow[b]{2}{*}{ Rata-Rata } & \multicolumn{2}{|c|}{ Referensi } \\
\hline & & & $\begin{array}{l}\text { Fiems et al. } \\
\text { (2003). }\end{array}$ & $\begin{array}{l}\text { Waritthitham } \\
\text { et al. (2010). }\end{array}$ \\
\hline Umur (tahun) & $2-4$ & $3 \pm 0,60$ & - & - \\
\hline Bobot Potong (kg) & $390-1.020$ & $572 \pm 130,85$ & 740,2 & 600,0 \\
\hline Bobot Karkas (kg) & $200-550$ & $312 \pm 66,00$ & - & - \\
\hline Persentase Karkas (\%) & $49,49-54,57$ & $51,5 \pm 1,25$ & - & - \\
\hline Marbling & Small - S.Abundant & Modest & 469,7 & 328,0 \\
\hline Quality Grade & Standart-Prime & Choice & - & - \\
\hline
\end{tabular}

Sumber : Data Primer Terolah, 2017.

Jika dibandingkan dengan Fiems et al. (2003) dan Waritthitham et al. (2010), produksi karkas yang dihasilkan sapi peranakan Simmetal di RPH kota Semarang ini lebih kecil, namun jika dibandingkan dengan karkas sapi impor asal Australia, khususnya pada produksi karkas sapi Brahman Cross (BX) memiliki rata-rata produksi karkas yaitu 279(Thomas, 2016), maka karkas yang dihasilkan dari sapi peranakan Simmental yang dipotong di RPH Penggaron kota Semarang (Tabel 2) mampu bersaing dengan karkas yang diproduksi dan diimpor dari negara Australia. Upaya peningkatkan bobot potong sapi akan berdampak pada peningkatan bobot karkas yang dihasilkan, sehingga nantinya sapi-sapi peranakan Simmental di Indonesia akan mampu bersaing dalam mencukupi kebutuhan pasar daging serta menekan masuknya daging sapi impor khususnya dari Australia.

Berdasarkan uraian di atas maka dapat disimpulkan bahwa produktivitas karkas sapi peranakan Simmental yang dipotong di RPH kota Semarang masih belum maksimal baik dari segi kuantitas maupun kualitas. Karkas sapi peranakan Simmental yang dipotong di RPH juga memiliki potensi untuk bersaing dengan karkas sapi impor yang berasal dari negara Australia, sehingga upaya untuk memaksimalkan potensi produktivitas sapi peranakan Simmental di RPH Penggaron perlu dilakukan supaya nantinya sapi lokal Indonesia khususnya sapi peranakan Simmental akan mampu bersaing dengan sapi impor dalam upaya memenuhi kebutuhan daging nasional serta swasembada daging. 


\section{KESIMPULAN}

Berdasarkan hasil penelitian dapat disimpulkan bahwa sapi peranakan Simmental yang dipotong di RPH Penggaron Kota Semarang masih kurang optimum (umur 3 tahun, bobot potong 572 $\mathrm{kg}$, bobot karkas $312 \mathrm{~kg}$, persentase karkas $51,5 \%$, dan quality grade choice) dan masih memiliki potensi untuk ditingkatkan produktivitasnya baik dari segi kuantitas maupun kualitas, sehingga dengan demikian diharapkan produktivitas sapi peranakan Simmental di Indonesia dapat meningkat sehingga dapat menunjang upaya peningkatan produktivitas sapi nasional.

\section{SARAN}

Peningkatan produktivitas sapi peranakan Simmental yang dipotong di RPH Kota Semarang baik dari segi kuantitas maupun kualitas dapat dilakukan dengan cara memperbaiki manajemen pemeliharaan dengan berpedoman pada target umur, bobot potong, penilaian terhadap muscle score, dan body condition score.

\section{DAFTAR PUSTAKA}

Badriyah, N. 2014. Kesesuaian rumus Schoorl terhadap bobot badan sapi peranakan Ongole (PO). Jurnal Eksakta 2 (2) : 99 - 158.

Direktorat Jenderal Peternakan dan Kesehatan Hewan. 2015. Statistik Peternakan dan Kesehatan Hewan 2015. Direktorat Jenderal Peternakan dan Kesehatan Hewan Kementerian Pertanian Republik Indonesia, Jakarta.

Fiems, L.O., S.D. Campeneere, W.V. Caelenberg, J.L.D. Boever, and J.M.
Vanacker. 2003. Carcass and meat quality in double muscled Belgian blue bulls and cow. Meat Science 63 (2003) : $345-352$.

Hollad, R. and D. Loveday. 2013. Understanding Yield Grades and Quality Grades for Value-Added Beef Producers and Marketers. Institute of Agriculture, University of Tennessee, Knoxville.

Murtidjo, B. A. 1992. Beternak Sapi Potong. Kanisius, Yogyakarta.

Rossi, J and T.W Wilson. 2006. Body Condition Scoring Beef Cows. The University of Georgia Cooperative Extension, Athens.

Syafrizal. 2011. Keragaman genetik gapi persilangan Simmental di Sumatera Barat. Jur. Embrio 4 (1) : 48-58.

Tatum, D. 1997. Beef Grading. American Meat Science Association, America.

Thomas, B. 2016. Australian Cattle Industry Projections 2016. Meat and Livestock Australia, New South Wales.

USDA Agricultural Marketing. 1996. U.S. Standards for Grades of Slaughter Cattle and Standards for Grades of Carcass Beef. USDA Agricultural Marketing Services, Government Printing Office, Washington D.C.

Waritthitham, A., C. Lambertz, H.J. Langholz, M. Wicke, and M. Gauly. 2010. Assessment of beef production from Brahman $\mathrm{x}$ Thai native and Charolais $\mathrm{x}$ Thai native crossbred bulls slaughtered at different weights. I: Growth performance and carcass quality. Meat Sci. 85 (2010) : 191 - 195. 


\title{
PENGARUH PENGGUNAAN TEPUNG DAUN MENGKUDU (Morinda cirifolia) DALAM PAKAN TERHADAP KUALITAS FISIK TELUR AYAM (Effect of Noni Leaf Meal in The Diet On Chicken Eggs Fisis Quality)
}

\author{
Y. Trianto, A.Hintono dan L. D. Mahfudz \\ Program Studi S1 Peternakan \\ Fakultas Peternakan dan Pertanian Universitas Diponegoro, Semarang. \\ inditik@yahoo.com
}

\begin{abstract}
ABSTRAK
Penelitian ini bertujuan untuk mengkaji pengaruh penggunaan tepung daun mengkudu (Morinda cirifolia) dalam pakan terhadap kualitas fisik telur ayam. Materi yang digunakan sebanyak 200 ekor ayam petelur umur 22 minggu dengan bobot badan $1513,5 \pm 13,67$ g. Bahan pakan yang digunakan adalah konsentrat, jagung kuning, bekatul, dan tepung daun mengkudu. Rancangan yang digunakan adalah Acak Lengkap terdiri dari 4 perlakuan dengan 5 kali ulangan dan tiap unit percobaan terdiri dari 10 ekor ayam petelur. Pakan perlakuan yang digunakan antara lain T0 (kontrol) = ransum tanpa penggunaan tepung daun mengkudu; $\mathrm{T} 1=$ ransum dengan penggunaan tepung daun mengkudu, $\mathrm{T} 1$ = ransum dengan penggunaan tepung daun mengkudu $2,5 \% ; \mathrm{T} 2=$ ransum dengan penggunaan tepung daun mengkudu 5\%; dan T3 = ransum dengan penggunaan tepung daun mengkudu 7,5\%;. Variabel yang diamati adalah tebal cangkang, haugh unit dan skor warna kuning telur. Data dianalisis menggunakan analisis ragam (ANOVA) dari Rancangan Acak Lengkap (RAL) dan apabila terdapat perbedaan dilanjutkan dengan Uji Jarak Berganda Duncan's. Hasil penelitian menunjukkan bahwa penggunaan tepung daun mengkudu (Morinda cirifolia) dalam pakan tidak berpengaruh nyata $(\mathrm{P}>0,05)$ terhadap haugh unit namun berpengaruh nyata $(\mathrm{P}<0,05)$ terhadap tebal cangkang dan skor warna kuning telur. Simpulan dari penelitian ini adalah penggunaan tepung daun mengkudu tidak menurunkan nilai haugh unit, namun dapat meningkatkan tebal cangkang dan warna kuning telur ayam.
\end{abstract}

Kata Kunci : Ayam Petelur, Tepung Daun Mengkudu dan Kualitas Fisik Telur

\section{ABSTRACT}

The research aimed to study the effect of noni leaf meal in the diet on chicken eggs fisis quality. The material used was 200 laying hens, aged 22 weeks with initial body weight $(B W)$ average of 1513,5 $\pm 13,67$ gram $(C V=2,02 \%)$. Feedstuffs used were concentrate, yellow corn, rice bran, and noni leaf meal. The experiment used Completely Randomized Design with 4 treatments of ration, each consisted of 5 replications of 10 layer hens. The treatments given were TO (control) = feed without noni leaf meal; $T 1=$ feed with 2,5\% noni leaf meal; T2 = feed with 5\% noni leaf meal; and T3: feed with 7,5\% noni leaf meal. Variables measured were eggshell thickness, haugh unit and yolk color score. Data were subjected to analysis of variance (ANOVA) of the Completely Randomized Design (CRD), if significant results were obtanined, then followed by Duncan's Multiple Range Test. The result of the research showed that the use of noni leaf meal in the diet did not significantly affected $(P>0,05)$ haugh unit, but it significantly affected $(P<0,05)$ eggshell thickness and yolk color score. Based on this research result, it 
was concluded that use of noni leaf meal in the diet did not increase haugh unit, but decrased eggshell thickness and yolk color score.

Keyword : Laying Hens, Noni Leaf Meal, Egg Fisis Quality.

\section{PENDAHULUAN}

Peranan telur dalam kehidupan sehari-hari di masyarakat Indonesia tampak semakin penting. Hal ini disebabkan karena harga telur relatif murah sehingga dapat dijangkau oleh masyarakat, mudah didapat, mudah disajikan, dan bioaktifnya tinggi. Disamping mengandung kadar protein yang tinggi, telur juga merupakan sumber zat besi, beberapa mineral lain dan vitamin, sehingga telur merupakan bahan pangan hewani yang dapat dikonsumsi oleh manusia pada segala umur.

Telur mempunyai kekurangan secara fisik dan kimiawi. Keadaan fisik mencakup hal berat telur, kondisi cangkang telur (tipis dan tebal) dan kebersihan cangkang telur. Standar ukuran dalam pemasaran telur adalah 56,7 gram per butir (Sumarni dan Nan Djuarnani, 1995). Kulit yang tipis relatif berpori lebih banyak dan besar, sehingga mempercepat turunnya kualitas telur akibat penguapan dan pembusukan lebih cepat. Semakin kotor keadaan cangkang telur maka semakin banyak mikroba masuk melalui pori-pori dan mengakibatkan kerusakan telur yang lebih cepat. Kerusakan bagian luar telur mempengaruhi kualitas fisik bagian dalam yang dapat mengakibatkan kuning dan putih telur tercampur. Selain itu, salah satu faktor kekurangan yang mempengaruhi penerimaan masyarakat terhadap kualitas fisik telur adalah warna kuning telur. Konsumen pada umumnya lebih memilih telur ayam yang kuning telurnya berwarna kemerahan sehingga memiliki skor warna kuning antara 11-13. Total lemak dalam kuning telur adalah sebesar 29,98\% dari bobot kuning telur dan kolesterol sebesar $5,20 \%$ dari bobot kuning telur (Rahayu, 2003).

Komposisi fisik dan kualitas telur dipengaruhi oleh beberapa faktor, diantaranya bangsa ayam, umur, musim, penyakit dan lingkungan, pakan yang diberikan serta sistem pemeliharaan. Pakan merupakan salah satu faktor yang paling penting dalam menentukan kualitas fisik telur. Pakan yang berkualitas baik akan menghasilkan telur yang berkualitas baik pula. Namun perlu diberikan pakan alternatif untuk menekan biaya produksi. Pakan alternatif sebaiknya memiliki kandungan nutrisi yang tinggi, mudah didapat dan diolah serta tidak menimbulkan bahaya bagi ternak yang memakannya. Salah satu pakan alternatif yang dapat digunakan adalah tanaman mengkudu.

Daun mengkudu mengandung zat nutrisi seperti protein kasar 22,11\%, Ca 10,30\%, Fe 437 ppm, Zn 35,80 ppm dan $\beta$ karoten 161 ppm (Wardiny dan Sinar, 2008). Daun mengkudu memilki kandungan Ca yang tinggi berperan dalam kualitas cangkang atau kerabang telur. Pada daun mengkudu juga memiliki $\beta$-karoten yang berfungsi sebagai pigmen warna pada kuning telur yang diharapkan dapat meningkatkan skor warna kuning telur.

Berdasarkan uraian diatas maka perlu dilakukan penelitian yang menggunakan tepung daun mengkudu sebagai salah satu bahan ransum unggas karena selain yang mengandung gizi cukup tinggi, harganya murah dan ketersediaannya melimpah.

Tujuan dari penelitian ini adalah untuk mengetahui pengaruh penggunaan 
tepung daun mengkudu (Morinda cirifolia) dalam pakan terhadap kualitas fisik telur. Adapun sifat fisik yang diukur adalah tebal cangkang, haugh unit dan skor warna kuning telur.

\section{MATERI DAN METODE}

Penelitian tentang pengaruh penggunaan tepung daun mengkudu (Morinda cirifolia) dalam pakan terhadap warna kuning dan indeks haugh telur dilaksanakan selama 2 bulan dimulai pada tanggal 20 Oktober 2014 sampai dengan 20 Desember 2014 di Desa Mijen, Kecamatan Mijen Kota Semarang.

Materi yang digunakan dalam penelitian ini ayam petelur periode layer strain Isa Brown berumur 22 minggu sebanyak 200 ekor dengan bobot badan $1513,5 \pm 13,67 \mathrm{~g}$ ditempatkan di kandang baterai berupa kotak yang terbuat dari kawat. Bahan pakan yang digunakan dalam penelitian ini adalah konsentrat, jagung kuning, bekatul, dan tepung daun mengkudu.
Penelitian ini menggunakan rancangan acak lengkap (RAL) terdiri dari 4 perlakuan. Masing-masing perlakuan terdiri dari 5 ulangan, setiap unit percobaan terdiri dari 10 ekor ayam petelur umur 22 minggu. Pengolahan data dilakukan dengan prosedur analisis Ragam (analysis of variance / anova) dan dilanjutkan dengan Uji Wilayah Berganda Duncan pada taraf 5 $\%$.

Perlakuan penggunaan tepung daun mengkudu, yaitu

T0 : perlakuan tanpa penggunaan tepung daun mengkudu

T1 : pakan dengan penggunaan 2,5\% tepung daun mengkudu.

T2 : pakan dengan penggunaan $5 \%$ tepung daun mengkudu.

T3 : pakan dengan penggunaan $7,5 \%$ tepung daun mengkudu.

Komposisi dan kandungan gizi masing - masing ransum penelitian tertera Tabel 1. Ransum yang diberikan dengan protein $16-17 \%$ dan diberikan sebanyak 120 gram/ekor/hari.

Tabel 1.Komposisi dan Kandungan Nutrisi Ransum

\begin{tabular}{|c|c|c|c|c|}
\hline \multirow{2}{*}{ BahanPakan } & T0 & $\mathrm{T} 1$ & $\mathrm{~T} 2$ & T3 \\
\hline & \multicolumn{4}{|c|}{---------.\%-------- } \\
\hline Tepung daun mengkudu & 0,00 & 2,50 & 5,00 & 7,50 \\
\hline Konsentrat & 35,00 & 34,00 & 34,00 & 34,00 \\
\hline Jagung giling kuning & 50,00 & 50,00 & 50,00 & 50,00 \\
\hline Dedak halus & 15,00 & 13,50 & 11,00 & 8,50 \\
\hline Total & 100,00 & 100,00 & 100,00 & 100,00 \\
\hline \multicolumn{5}{|l|}{ Kandungan Nutrisi: } \\
\hline EM (Kkal/kg) & $3.480,35$ & $3.468,97$ & $3.465,69$ & $3.462,42$ \\
\hline Protein Kasar $(\%)$ & 16,75 & 16,69 & 16,88 & 17,06 \\
\hline Serat Kasar (\%) & 4,74 & 5,25 & 5,695 & 6,14 \\
\hline Lemak Kasar (\%) & 5,14 & 5,16 & 5,18 & 5,19 \\
\hline Calsium (\%) & 4,23 & 4,17 & 4,22 & 4,28 \\
\hline Phospor (\%) & 0,88 & 0,85 & 0,82 & 0,79 \\
\hline
\end{tabular}

Keterangan : Kandungan gizi berdasarkan perhitungan hasil analisis proksimat bahan pakan di Laboratorium Pusat Studi Pangan dan Gizi Universitas Gadjah Mada, 2014. 
Parameter penelitian dan cara pengambilan data dalam penelitian ini meliputi ketebalan cangkang, haugh unit, dan warna kuning telur. Pengambilan data dimulai pada minggu ketiga sebelum penelitian berakhir. Pengambilan data diawali dengan mempersiapkan peralatan berupa timbangan digital, dept micrometer, kaca datar,micrometer, dan yolk color fan.

Pengukuran tebal kerabang dilakukan dengan menggunakan mikrometer yang terdiri dari 3 bagian telur yaitu bagian ujung atau lancip, bagian tengah dan bagian bawah atau tumpul dengan menggunakan micrometer dinyatakan $\mathrm{mm}$, Pengukuran Haugh Unit untuk mengetahui kekentalan telur, ditentukan berdasarkan hubungan logaritma tinggi albumen (mm) dengan berat telur (g) dilakukan dengan menimbang berat telur dan mengukur tinggi albumen menggunakan tripold mikrometer, selanjutnya dihitung menggunakan rumus Austic dan Nesheim (1990):

$\mathrm{HU}=100 \log \left(\mathrm{h}+7,57-1,7 \mathrm{~W}^{0,73}\right)$

Keterangan :

$\mathrm{H}$ : Haugh Unit

W : berat telur utuh $(\mathrm{g})$

$\mathrm{h}$ : tinggi putih telur kental $(\mathrm{mm})$

Warna kuning telur diukur dengan yolk color fan dengan angka pengukur 1 15. Semakin besar angka pengukur maka semakin gelap warna telur yang diperoleh.

\section{HASIL DAN PEMBAHASAN}

Tabel 2. Rata-rata Tebal Cangkang, Skor Warna Kuning Telur dan Haugh Unit Ayam Petelur.

\begin{tabular}{cccc}
\hline Perlakuan & Tebal Cangkang $(\mathrm{mm})$ & $\begin{array}{c}\text { Skor Warna Kuning } \\
\text { Telur }\end{array}$ & Haugh Unit \\
\hline T0 & $0,41^{\mathrm{c}}$ & $8,00^{\mathrm{c}}$ & $90,38^{\mathrm{ns}}$ \\
T1 & $0,42^{\mathrm{ab}}$ & $10,20^{\mathrm{ab}}$ & $92,77^{\mathrm{bs}}$ \\
T2 & $0,44^{\mathrm{bc}}$ & $10,00^{\mathrm{b}}$ & $87,46^{\mathrm{ns}}$ \\
T3 & $0,46^{\mathrm{a}}$ & $11,00^{\mathrm{a}}$ & $85,35^{\text {ns }}$ \\
\hline
\end{tabular}

Keterangan : 1) nilai rata-rata dengan huruf berbeda pada kolom yang sama menunjukkan perbedaan nyata $(\mathrm{P}<0,05)$.

2) ns: tidak berbeda nyata $(\mathrm{P}>0,05)$.

\section{Pengaruh Perlakuan terhadap Tebal Cangkang}

Rataan tebal cangkang pada telur ayam yang diperoleh adalah T0 sebesar $0,4075 \mathrm{~mm}, \mathrm{~T} 1$ sebesar $0,4220 \mathrm{~mm}, \mathrm{~T} 2$ sebesar 0,4380 mm, dan T3 sebesar 0,4600 mm. Hasil analisis secara statistik menunjukkan bahwa perlakuan ransum dengan penggunaan tepung daun mengkudu menunjukkan berpengaruh nyata $(\mathrm{p}<0,05)$ terhadap tebal cangkang. Hal ini disebabkan kandungan $\mathrm{Ca}$ dan $\mathrm{P}$ pada daun mengkudu yang tinggi. Proses pembentukan cangkang sangat dipengaruhi kandungan zat gizi dalam pakannya. Diperlukan ketersediaan cukup mineral pembentuk deposit atau partikel kapur, yaitu garam-garan kalsium $(\mathrm{Ca}, \mathrm{P})$ dalam jumlah dan mutu yang cukup. Ketebalan cangkang telur banyak dipengaruhi oleh kadar kalsium dalam ransum yang akan menentukan ketersediaan garam-garam kalsium dalam darah untuk pembentukan telur (Yuwanta, 2004). Selanjutnya Achmanu (2010) menyatakan bahwa semakin tebal cangkang telur berarti kandungan $\mathrm{Ca}$ juga semakin tinggi. 


\section{Pengaruh Perlakuan terhadap Haugh Unit}

Rataan indeks haugh pada telur ayam yang diperoleh adalah T0 sebesar 90,38,T1 sebesar 92,77, T2 sebesar 87,46 dan T3 sebesar 85,35. Hasil analisis secara statistik menunjukkan bahwa perlakuan ransum dengan penggunaan tepung daun mengkudu menunjukkan tidak berpengaruh nyata $(p<0,05)$ terhadap indeks haugh. Hal ini disebabkan pengamatan dilakukan dengan waktu yang sama saat pengambilan telur dan dalam kondisi segar.Stadelman and Cotterill (1977) menyatakan bahwa nilai HU tergantung pada tinggi rendahnya bobot telur dan tebal albumen. Jika bobot telur menurun akibat penyimpanan, maka ada kecenderungan tebal albumen dan nilai $\mathrm{HU}$ akan menurun juga

\section{Pengaruh Perlakuan terhadap Warna Kuning Telur}

Rataan warna kuning telur ayam yang diperoleh adalah T0 sebesar 8, T1 sebesar 10, T2 sebesar 10, dan T3 sebesar 11. Hasil analisis secara statistik menunjukkan bahwa perlakuan ransum dengan penggunaan tepung daun mengkudu menunjukkan pengaruh nyata $(p<0,05)$ terhadap warna kuning telur. Hal ini disebabkan warna atau pigmen yang terdapat dalam kuning telur sangat dipengaruhi oleh beta-karoten dari tepung daun mengkudu.

Pakan mempengaruhi warna dari kuning telur, yaitu bahan pakan yang mengandung pigmen karotenoid terutama pigmen beta karoten dan xantofil. Bahan pakan yang banyak mengandung pigmen betakaroten dan xantofil diantaranya banyak terkandung pada hijauan atau daundaunan (Sujana et al 2006). Pewarnaan kuning telur yang optimal pada umumnya disebabkan kayanya kandungan karoten dalam ransum (Hamilton et al., 1990; Lai et al.,1996). Unggas mengkonsumsi ransum yang mengandung karotenoid lebih tinggi akan menghasilkan telur dengan intensitas warna kuning telur yang lebih tinggi pula (Udedibie \& Opara, 1998).

\section{SIMPULAN DAN SARAN}

Simpulan dari penelitian ini adalah penggunaan tepung daun mengkudu tidak menurunkan nilai haugh unit, namun dapat meningkatkan tebal cangkang dan warna kuning telur ayam.

\section{DAFTAR PUSTAKA}

Achmanu, Muharlien dan R. Fajar. 2010. Efek Lantai Kandang (Renggang dan Rapat) Dan Imbangan Jantan Betina Terhadap Fertilitas, Daya Tetas dan Kematian Embrio pada Burung Puyuh (Coturnix-Coturnix Japonica). JIIPB 20(1) : 48-54

Austic, R. E. and M. C. Nesheim. 1990. Poultry Production. 13th Ed. Lea and Febiger, Washington.

Hamilton, D.B., F.J. Tirado and F. GarciaHernandez.1990. Deposition in egg yolks of the carotenoids fromsaponified and unsaponified oleoresin of red peper(Capsicum annuum) fed to laying hens. Poult. Sci. 69:462-470.

Lai,S.M.,J.I.Gray,C.J.Flegaland T. Cooper. 1996. Deposition of carotenoids in eggs from hens fed diets containing saponified and unsaponified oleoresin paprika. J. Sci. Food Agric. 72: 166-170

Rahayu, W.P. dkk. 2003. Klarifikasi Bahan Pangan dan Resiko Keamanannya. PT Gramedia Pustaka Utama, Jakarta.

Stadelman, W.J. and O.J. Cotterill, 1977. Egg Science and Technology, 2nd 
Ed. Avi Publishing Company

Inc.West Port Connecticut.

Sujana, E., Wahyuni, S. dan Burhanudin, H. 2006. Efek Pemberian Ransum yang Mengandung Tepung Daun Singkong, Daun Ubi Jalar, dan Eceng Gondok sebagai Sumber Pigmen Karotenoid Terhadap Kualitas Kuning Telur Itik Tegal. Jurnal Ilmu Ternak. Juni 2006. Vol. 6. No. 1,53-56

Sumarni dan Nan Djuarnani . 1995. Diktat Penanganan Pasca Panen Unggas. Departemen Pertanian. Balai Latihan Pertanian, ternak, Ciawi Bogor.

Udedibie, A.B.I. \& C.C. Opara. 1998. Responses of growing broilers and laying hens to the dietary inclusion of leaf meal from Alchornia cordifolia. Animal Feed Sci. and Tech. 71: 157-164

Wardiny, T.M. dan Sinar, T.E.A. 2008. Pengaruh Pemberian Mengkudu (Morinda cirifolia) terhadap Kandungan Kolesterol Telur Ayam. Laporan Penelitian. Universitas Terbuka-Jakarta.

Yuwanta, T. 2010. Pemanfaatan Kerabang Telur. Program Studi Ilmu dan Industri Peternakan. Fakultas Peternakan. Universitas Gajah Mada. Yogyakarta. 